\title{
Hearing the INAUdible
}

\section{Book Title:}

Sounding unsound:

Orientation into mysticism

\section{Book Cover:}

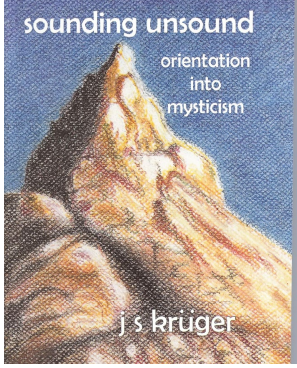

Author:

J.S. Krüger

ISBN:

0-620-37731-3

Publisher:

Aurora Press, Wierda Park; 2006, p. 323, R200.00*

*Book price at time of Review

\section{Review Title:}

Hearing the inaudible

\section{Reviewer:}

Jaco Beyers ${ }^{1,2}$

\section{Affiliations:}

${ }^{1}$ Department of Science of Religion and Missiology,

University of Pretoria,

Pretoria 0002, South Africa

${ }^{2}$ Nederdutch Reformed Church of Africa,

Verwoerdburg

congregation, South Africa

email:

jbeyers@telkomsa.net

\section{Postal address:}

PO Box 14125, Lyttelton

0140, South Africa

\section{How to cite this book} review:

Beyers, J., 2010, 'To hear the inaudible', Verbum et Ecclesia 31(1), Art. \#409, 2 pages. DOI: 10.4102/ve.v31i1.409

\section{This review is available} at:

http://www.ve.org.za

(c) 2010. The Authors. Licensee: OpenJournals Publishing. This work is licensed under the Creative Commons Attribution License.
Every human being is in search of deeper meaning. Man has a notion of the transcendental and expects to find something deeper hidden behind the directly perceivable matter. With this book, Krüger offers a guide to the seeker who is on such a religious quest. Krüger does not follow a conventional approach to the understanding of religion. This book is not about religion, at least not institutionalised religion. The content, however, addresses the spiritual need of every man.

In the search for deeper meaning, man is exposed to the multitude of claims and possibilities of religions. Krüger shows how man is actually in search of silence. Only after searching intensely does man reach silence. This silence is not the absence of sound, but the impossibility of sound. In this state of silence man becomes aware of the 'audible' deeper conversation (compare the title: Sounding Unsound). When the inaudible becomes audible man has discovered silence. The way to reach this silence is a mystic process (compare the subheading: Orientation into Mysticism).

Mysticism is knowledge of, and communication with, life. Mysticism becomes the way in which contact with the inaudible, the silence, is made. Krüger compares his understanding of mysticism with a high mountain. Human spirit has the inherent yearning to excel all things, to transcend all and to integrate with the absolute mystery which is the source of all things. Mysticism is not an exclusive phenomenon to one or a type of religion. Krüger refers to mysticism as a universal phenomenon part of human nature.

The book consists of four parts. In the first part (Ten Twin Problems), Krüger discusses 10 linked pairs, which are connected to the understanding of contact with the transcendental: something and nothing, matter and mind, human and nature, maximum and minimum, one and many, thing and think, is and ought, good and evil, life and death, relative and absolute. These links represent the most important dilemmas with which religion and mysticism is confronted. Krüger does not pretend to present the final solution, but rather to unveil the shortcomings of human intellect.

The second part of the book consists of a discussion of the structural elements of the understanding of the transcendental. This part of the book highlights the different forms mysticism have taken on over history and indicating the underlying connections.

One of the basic principles with which Krüger works is his understanding of the relationship between man and cosmos. The unbreakable unity between these two becomes the basis for mysticism. Communication between man and cosmos gradually disintegrated due to the separation brought about an exclusively scientific understanding of reality. Mysticism wants to re-establish these channels of communication. According to Krüger, the separation between man and cosmos contributes to the ecological crisis of our times.

Man, according to Krüger, is in the midst of cosmos, is cosmos itself. That which surrounds man is the fullness of all things, totality (representing all that can be said and be known), underneath man is the negative unground (as represented in human fear, consciousness and danger). Above man is the infinity

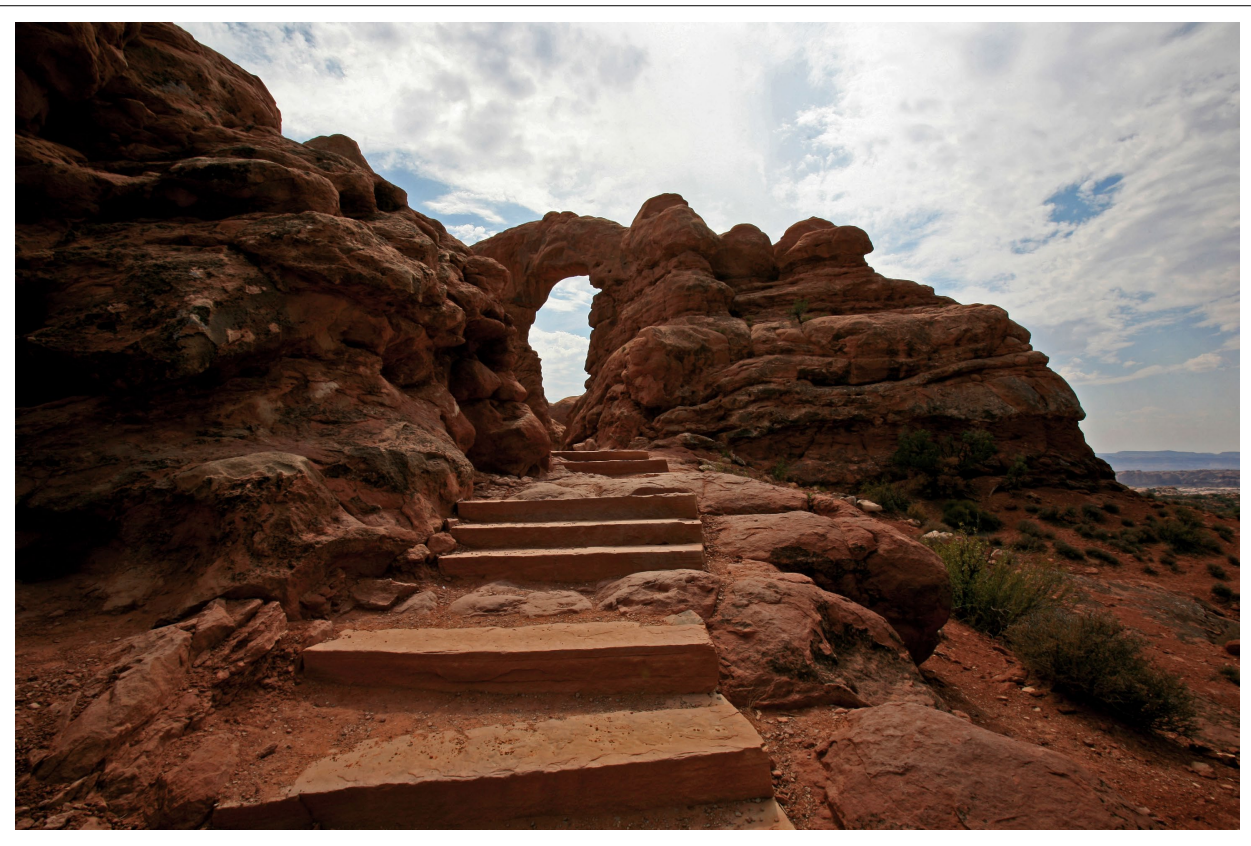

Source: http://www.sxc.hu/photo/1234362

The human search for the Absolute is an unending search 
of positive possibilities (manifested in the conviction of the unknown, limitlessness). When confronted with this greatness, the only suitable reaction is silence.

Human nature consists of spirit. In the same way does the cosmos consist of Spirit (at times called different names like Totality-plus-Infinity, Energy, Power, Life, Nature, God). Spirit consists of body/matter, soul and mind (consciousness). On the ground of Spirit that flows through everything, man can make contact with the cosmos. Krüger explains at length the history of the understanding as well as his own understanding of the manifestation of Spirit in terms of matter, soul and mind. Mysticism is the way of regaining contact between human spirit and Spirit of the cosmos.

In the third part of the book (Mountain), Krüger at first discusses what man has in common regarding body, soul (emotions, feeling and will) and mind (consciousness). Secondly, Krüger discusses the historic development of human thought on religious ideas and practices as manifested in different communities. $\mathrm{He}$ explains how ideas and practices can be exchanged. It is clear that the structural and historic research can not be seperated.

The third part of the book also gives a historic overview of the understanding of reality, religion, tradition, morality, ritual, feeling and understanding. Krüger identifies six epochs into which the growth of human awareness of the cosmic mystery can be divided. These epochs developed separately in different times and places. They do not follow chronologically. Some earlier epochs can still be identified in current communities. Krüger is convinced that epoch VI, representing the time from the 19th century onwards, will bring a new awareness to man as spiritual being. The great world religions are in a crisis. Their roots lie in an ancient understanding of reality. It will be impossible to implement a new modern orientation without loosing followers.

Reaction to modern culture manifests in three possible ways: (1) the emergence of new religions and cults, (2) fundamentalism and (3) the emergence of spirituality and mysticism. Mysticism follows its own path to repair the relationship with deeper sources of life in an intuitive fashion. Epoch VI is characterised by human endeavour to regain connection between human spirit and the cosmic Spirit.

In the final part of the book (An Integral Approach), Krüger summarises the different models of mysticism that exist and influence one another. These models are discussed by way of an evaluation from an insider and outsider perspective respectively. The human search for the Absolute is an unending search. The mystical experience, Krüger says, is like a flower. It blooms in reaction to its surroundings. The beauty of the flower suggests the existence of deeper beauty elsewhere. Even if the flower dies in winter, Life does not stop. In spring, a new flower can be expected. This expectation to see Life bloom exceeds human culture, history and religion only because the search is inherently part of human nature and because the Absolute remains somewhere hidden silently waiting to be heard. 